\section{EDUCATION}

Research, Innovation and Solutions on-line ${ }^{\circledR}$
Electronic Journal of Research

in Educational Psychology

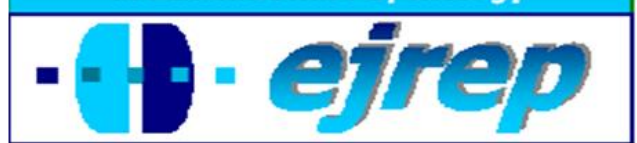

\title{
Introducing National Tests in Swedish Primary Education: Implications for Test Anxiety
}

\author{
Mikaela Nyroos $^{1}$ \& Carola Wiklund-Hörnqvist ${ }^{2}$ \\ ${ }^{1}$ Department of Applied Educational Science, Umeå University, Umeå \\ ${ }^{2}$ Department of Psychology, Umeå University, Umeå
}

\section{Sweden}

Correspondence: Mikaela Nyroos. Dep. of Applied Educational Science, Umeå University, 90187 Umeå, Sweden. E-mail: mikaela.nyroos@edusci.umu.se

(C) Education \& Psychology I+D+i and Editorial EOS (Spain) 


\begin{abstract}
Introduction. The Swedish government has decided to introduce national tests in primary education. Swedish pupils in general have few tests and a recognised possible adverse effect of testing is test anxiety among pupils, which may have a negative impact on examination performance. However, there has been little research on effects of testing on young children within the Swedish context. The current study explores the experience of test anxiety related to achievement in mathematics and Swedish in a sample of 40 grade 3 pupils.
\end{abstract}

Method. A modernised standardised test for measuring children's test anxiety. Academic achievement in various mathematical and Swedish domains.

Results. Test anxiety, in particular its subcomponent autonomic reactions, is related to poor performance in Swedish. In mathematics there is an especially marked relationship between the subtest Written arithmetic and test anxiety, particularly its subcomponent anxious thoughts.

Conclusion. Test anxiety seems not to be a general problem in present Swedish young sample, however, cautions need to be taken regarding the acquiring of algorithms and number of tests given.

Keywords: test anxiety; children; mathematics; Swedish 


\section{La implantación de examenes nacionales en la Educa- cion Primaria de Suecia. Implicaciones para Ansiedad ante las Pruebas.}

\section{Resumen}

Introducción. El Gobierno de Suecia ha decidido introducir exámenes oficiales en la educación primaria. En general, los alumnos suecos no tienen muchos exámenes y uno de los posibles efectos adversos reconocidos es la ansiedad que sufren los estudiantes antes los exámenes, que puede afectar negativamente a la ejecución del mismo. Sin embargo, se ha investigado poco sobre los efectos de los exámenes en niños en el contexto educativo sueco.

Objetivos. Este estudio explora la experiencia de la ansiedad antes los exámenes en relación con el rendimiento en matemáticas y sueco de una muestra de 40 alumnos de grado 3.

Método. Se utilizó un test estandarizado y modernizado para medir la ansiedad de los niños ante los exámenes. También se evaluó el rendimiento académico, en varios campos de matemáticas y sueco.

Resultados. La ansiedad ante los exámenes, en particular el subcomponente de sus reacciones autónomas, está relacionada con un rendimiento deficiente en Sueco. En matemáticas existe una marcada relación entre la prueba escrita de aritmética y la ansiedad ante el examen, particularmente el subcomponente de pensamientos que generan ansiedad.

Conclusión. La ansiedad ante los exámenes no parece ser un problema general en la muestra de jóvenes suecos, sin embargo, es necesario proceder con precaución en cuanto a la adquisición de algoritmos y el número de exámenes realizados.

Palabras clave: ansiedad antes los exámenes; niños; matemáticas; sueco 


\section{Introduction}

Standardised national assessments of elementary and secondary pupils take place in most industrialised countries, and the importance placed on them appears to be increasing (O’Donnell, Sargent, Byrne, White \& Gray, 2009). The gradual growth in the use of national testing can be partly explained by various international comparative studies of education, e.g. the Trends in International Mathematics and Science Study - TIMSS and the Programme for International Student Assessment - PISA (Robertson, 2005). In addition, examinations tend to be favoured by policy makers, educators, and the public, who expect them to serve various purposes, including curriculum development (Pellegrino \& Goldman, 2008). Consequently many nations invest considerable resources into diverse assessment programs (Doig 2006) and evaluation activities, as an accepted part of the educational process (Natriello, 1987).

Exams can trigger intense emotions, both potential and openly expressed (Pekrun, Goetz, Perry, Kramer, Hochstadt \& Molfenter, 2004). Even though positive emotions are described about as often as negative emotions among students, anxiety is the most commonly reported emotion related to exam-taking (Pekrun, Goetz, Titz \& Perry, 2002). Performance in achievement situations is known to be increased by positive motivation (Rand, Lens \& Decock, 1991), but for example Wolf and Smith (1995) found that high motivation in combination with high anxiety produced almost the same levels of performance as low motivation in combination with low anxiety. They concluded that while high motivation is clearly advantageous in optimizing test performance, the anxiety that often accompanies increased levels of motivation could have an unfavourable effect. The study reported herein focuses on this negative influence of testing on academic performance, i.e. test anxiety.

While test anxiety is primarily thought of as having debilitating effects on academic performance (King, Ollendick \& Gullone, 1991), individuals seem to perform best under intermediate levels of it (Hopko, McNeil, Zvolensky \& Eifert, 2001). According to the YerkesDodson Law, a plot of academic performance against levels of test anxiety would take the form of an inverted ' $U$ '; as test anxiety increases, academic performance initially rises (reflecting the beneficial and motivating effects of anxiety) but then peaks and falls as levels of anxiety become debilitating (McDonald, 2001). However, children vary in their responses to test anxiety; levels that induce good performance in some might have pronounced negative impacts on the performance of others (Connor, 2003). There is a substantial body of evidence 
indicating that as a group, people with high test anxiety underperform in examinations in both laboratory settings and classrooms (Zeidner, 2007). Meijer (2001) showed that test anxiety can introduce bias that conceals pupils' that conceals pupils' true potential; under such circumstances, test results would be misleading and could potentially have negative effects on pupils' future aspirations (Zeidner \& Matthews, 2005). Examinations that have such debilitating effects are not educationally justifiable or defensible (Reay \& William, 1999). Equity in assessment requires fair and just practice in testing, including the interpretation of results for all groups taking examinations (Gibbs, 1995). Although correlations between test anxiety and exam performance might be modest, its influence on the number of children underperforming on an exam is potentially considerable and must therefore be taken into account (McDonald, 2001).

In Sweden, examinations developed by teachers have been commonly applied, but compared with other countries Swedish pupils have generally had very few tests during compulsory education (OECD, 2005; Skolverket, 2007). However, in recent years rankings of Swedish pupils in international comparisons have declined. In response, the Swedish government has introduced national tests at increasingly early school grades (Krantz, 2010), and national tests (in mathematics and Swedish) that will be mandatory for children in grades 3 and 5 are being introduced in 2010. Under the new national regime the number of tests will increase, and during a 10-week-period the pupils will take several subtests in mathematics and Swedish. This study discusses the educational implications of test anxiety associated with these tests.

A certain level of anxiety might be essential for optimal performance in testing situations, and only modest levels of test anxiety have been reported by young children. However, if testing is to be used in a learning environment, it is important to recognise its pervasive negative effects and the extent to which externally imposed testing programs may inhibit and even drive out thoughtful classroom practices (Shepard, 2000). Both the reasons for assessing pupils and the methods used may significantly affect some pupils' learning and educational experience (Harlen, 2007). In a review of standardised assessment in Europe Mons (2009) for example noted that the effects of national tests appear random, that evidence for the link between educational equality and assessment appears contradictory, and that there is no theoretical basis that can adequately explain how assessment enhances learning. She therefore concluded that there seems to be no consensus regarding the benefits of standardised assessment. 
On the contrary, it frequently appears that the more standardised tests are used, the more criticism arises (Harlen, 2007). Many countries, including Sweden, use national tests for the formative purpose of assessment for learning, rather than the assessment of learning (Eurydice, 2009). With more tests there may, however, apparently be increased risks of some pupils and specific groups experiencing test anxiety. Hugo (2007) also argues that holding tests in earlier grades in school could have adverse consequences for low achievers. Examinations tend to stigmatise this pupil group and further decrease their motivation to do well in school. Consequently, there is a need for evaluations of the likely impact of the new national tests on younger pupils.

Swedish research on testing has largely focused on statistical and psychometric measurements of older children (Lindberg, 2005); ways in which tests influence learning in Sweden has received limited attention (Korp, 2003). There have also been limited international assessments of the effects of test anxiety on younger pupils in a classroom environment (Connors, Putwain, Woods \& Nicholson, 2009; Kornell \& Son, 2007). Despite the existence of more than 1000 publications on test anxiety (Stöber \& Pekrun, 2004), comparatively little work in this area has been conducted in Sweden. While it seems that there are only minor differences between nations in relation to test anxiety (Seipp \& Schwarzer, 1996), it is generally acknowledged that pupils are subject to the influence of both cultural and social factors, and so previous research findings should not be uncritically generalised to other national populations (Zeidner, 1990). Finally, while test anxiety effects have been observed across a range of school subjects, relatively little is known about how it affects individual subtopics within them. Therefore, in addition to examining the incidence and severity of test anxiety in a sample of Swedish pupils, our study also considers the multidimensionality of two school subjects.

\section{Test Anxiety}

Anxiety is a universally experienced subjective emotional response described as a highly unpleasant feeling of distress accompanied by physiological, cognitive and behavioural reactions (Finch \& McIntosch, 1990). Anxiety is a very circumscribed condition and thus an important variable to consider in education (Beidel \& Turner, 1988). However, test anxiety is not a diagnosable disorder (Bodas, Ollendick \& Sovani, 2008), but rather a syndrome or a symptom (Legrand, McGue \& Iacono, 1999) that may be a major factor weakening academic performance at all levels (Birenbaum \& Gutvirtz, 1993). Test anxiety is believed to be a lear- 
ned condition, typically evoked in educational settings, and developed during early school years (Pekrun, 2000). Several factors can potentially affect the development of test anxiety. However, these are not all active at the same time during a child's development, and it is their influence at the specific time on the individual and his/her experience that shapes their unique reactions to a test situation (McDonald, 2001).

The construct of test anxiety can be theorised as being complex, multi-dimensional, and dynamic. Test-anxious individuals can be characterized by their thoughts, somatic reactions, feelings and observable behaviours in evaluative situations. The specific response manifested depends on a variety of factors. Two empirically distinct but interrelated components of test anxiety are worry and emotionality (Zeidner, 2007). Worry represents the cognitive aspect of anxiety and concerns the person's own evaluation of his/her performance. Worry is experienced for a longer period of time than emotionality, setting in some days before the exam, and persisting throughout the test. The person's subjective awareness and understanding of their physiological reactions in different test situations comprises the emotionality component, i.e. the physiological aspect of anxiety. This affective aspect is present immediately before a test and then diminishes (Nasser, Takahashi \& Benson, 1997). Chung, O’Neil, Delacriz and Bewley (2005) believe that worry has a stronger negative influence on performance than emotionality. Worry is also sometimes categorised as a trait or a predisposition, while emotionality is seen as a state, experienced at specific points in time (Meijer, 2001). A state of emotionality, which is generally considered to be temporary, depends on the context of a given test and may vary with changes in the testing environment (Zeidner, 2007). However, whether test anxiety is related to disposition or situation remains open to debate. Thus, worry can be interpreted as a disposition or as a state, depending on the theoretical stance adopted (Meijer, 2001).

Research has repeatedly highlighted the association between anxiety and children's academic problems, such as leaving school early and educational underachievement (McDonald, 2001; Owens et al., 2008). Although the degree to which test anxiety affects performance and metacognitive precision may depend of the type of test (Miesner \& Maki, 2007), test anxiety remains a growing problem in diverse geographical and cultural settings (Bodas et al., 2008). Pupils of all achievement levels suffer and no age group is immune (Legrand et al., 1999). However, some variations as functions of sex, background and age have been observed (Richmond \& Rodrigor, 1988). Commonly girls (Chapell et al., 2005), low-achievers (Wig- 
field \& Eccles, 1989), and older children (Zeidner, 1998) report more test anxiety than other groups. Different subjects may also induce differing levels of stress in test situations; mathematics particularly seems to provoke anxiety among older pupils (Putwain, 2008). Corroborating this finding, Boekaerts, Otten and Voeten (2003) observed that some pupils who failed in mathematical tasks attributed their weak performance largely to a lack of ability, while failures in subjects such as history and English were more likely to be attributed to the nature of the tasks.

Females, regardless of cross-cultural setting and age, tend to report higher levels of test anxiety than males (Lowe \& Lee, 2008). This difference could be explained by worldwide socialisation practices that encourage women to show their feelings publicly and men to hold back or hide them (Bodas et al., 2008), or by the view that valuing school work and scholastic performance are not regarded as 'masculine' traits and hence are not valued by males (Martino, 1997; Skelton, 2001).

Research has shown that low-achievers in school are more affected by test anxiety than higher achieving groups (Birenbaum \& Gutvirtz, 1993). Pupils' perceived locus of control could partly explain this difference. Lower achieving, as well as younger, pupils seem to attribute success to external and uncontrollable factors, e.g. chance or other people. In comparison, high achieving and older pupils attribute achievement more to internal and controllable factors, such as capacity and hard work, although very young children have an optimistic belief in their capacity and often equate ability and effort ( $c f$. Natriello, 1987). Older and more successful pupils not only feel more in control of their performance in school, they also feel more competent as signs of achievement become more visible through comparative grades and results. Conversely, low achievers believe that their poor performance further signals their lack of ability; this deepens their negative attitudes, which may persist into adult life with far-reaching consequences (Newstead, 1998).

Children as young as 7 to 11 years old accurately recognise and understand negative emotions (Stone \& Lemanek, 1990) and children as young as 7 years old can experience stress as a result of formal testing (Connor, 2001). Test anxiety may emerge during the early years of school (Nicholls \& Miller, 1986). Bodas et al. (2008) propose that 25-40\% of schoolchildren experience test anxiety, while Yousefi et al. (2009) estimate that it is experienced by $10-30 \%$ of elementary and secondary pupils. McDonald (2001) cites estimates of its occu- 
rrence in school age children ranging from 10 to $41 \%$. Thus, although the existence of test anxiety is well attested, its distribution among age groups is still unclear. Some studies suggest that test anxiety may peak in junior high school, when gender differences also become more marked (Lowe \& Lee, 2008). Others have observed a peak at the fourth grade in elementary school (Araki, 1992). Paris, Lawton, Turner and Roth (1991) argue that motivation and readiness for tests seem to decrease with age, while anxiety increases. Bodas et al. (2008) studied differences in test anxiety among middle and high school students and found no corresponding increase in test anxiety levels as the children advanced to the higher grades. Wigfield and Eccles (1989) suggest that children's anxiety over the experience of failure is dominated first by emotional-affective responses, and characterised later by cognitive concern or worry about performing poorly. In sum, few studies have reported test anxiety to be as a widespread experience in primary school (Zeidner, 1998).

\section{Objectives}

The study reported herein has several objectives. The first is to gain an understanding of the experiences of test anxiety in a sample of Swedish grade 3 pupils. The second is to use univariate grouping and quantitative methods to explore associations between levels of test anxiety and academic achievement, and to thereby determine whether there is a negative correlation between the two, as observed in other age groups and contexts. The third is to examine the effects of test anxiety on performance in different topics in Swedish and Mathematics. The paper concludes with a discussion of the possible consequences of test anxiety and their educational implications.

\section{Method}

\section{Participants}

The participants in the present study consisted of all the 20 girls and 20 boys in two grade 3 classes belonging to the same school, aged 9-10 years. The data collection was guided by the ethical guidelines formulated by the Swedish Research Council (2006) regarding information, consent for participation, scientific use and confidentiality. All of the children gave their consent to participate and informed consent was obtained from the parents. 


\section{Instruments}

Test Anxiety. The Children's Test Anxiety Scale (CTAS; Wren \& Benson, 2004) is a refined and modernised 30-item version of the most widely used measure of this construct, the 30-item Test Anxiety Scale for Children (TASC; Sarason, Davidson, Lighthall, Waite \& Ruebush, 1969). The CTAS assesses an individual's level of apprehension or anxiety about testing on a 1-4 Likert scale, asking for participants' responses regarding how much anxiety they experience during testing. The CTAS is a self-reported pencil and paper instrument for measuring test anxiety in children. Children as young as 5 and 6 years can respond reliably to self-report measures of anxiety (Ialongo, Edelsohn, Werthamer-Larsson, Crockett \& Kellam, 1994). Self-reports are also considered to provide the most direct access to a person's subjective experiential states in test situations since they possess good psychometric properties (Zeidner \& Matthews, 2003). The CTAS has satisfactory reliability coefficients and high practicality in naturalistic field settings (Zeidner, 2007). The results of a recent study provide evidence for the reliability and validity of the CTAS scores and their interpretations when applied to younger Scandinavian pupils, supporting its use with present sample. The fit for the full model was reasonably good, the chi-square value $(374, \mathrm{~N}=172)$ was $700.54,(\mathrm{p}<.001)$, the comparative fit index was .80, the Tucker-Lewis index was .79, and the root mean square error of approximation was .07 (Nyroos, Korhonen, Linnanmäki \& Svens-Liavåg, 2011). The maximum score is the sum of the responses to each item on the scale; for each item, the subject can choose between four responses: $1=$ almost never; $2=$ some of the time; $3=$ most of the time; and 4 = almost always. The test comprised three dimensions: thoughts, 13 items, (e.g. "While I am taking tests I worry about failing"); autonomic reactions, 9 items, (e.g. "While I am taking tests my belly feels funny"); and off-task behaviours, 8 items, (e.g. "While I am taking tests I check the time").

Academic achievement. The Swedish Government has decided to introduce national examinations in grade 3. National examinations in these subjects will consist of several short subtests designed to assess some parts of the mathematics and Swedish syllabus goals for this age group. These examinations are to be administered within a ten-week period, on dates decided by the school. In the two classes studied here, pupils sat the examinations over a period of four weeks. The mathematics and Swedish examinations are connected by a story of two children on an adventure, with the aim of lessening the impact of the test situation (Skolverket, 2010). The first mandatory national examination in mathematics, implemented in spring 2010, consisted of seven tests: Statistics, Written arithmetic, Mental arithmetic, Time, Num- 
ber understanding, Fractions, and Area \& volume. The tasks were varied, ranging from exercises designed to assess basic numeracy to more complex tasks, and were expressed in different forms (e.g. drawing and writing); one component, Statistics, was assessed on the basis of a group assignment, and was excluded from our present study. The national examinations in Swedish consisted of eight subtests: Speech, Reading comprehension of facts, Reading comprehension of fiction, Reading aloud, Writing facts, Writing fiction, Grammar \& spelling, and Legibility. Scores were given only for Reading comprehension of fiction and Reading comprehension of facts; performance in the other six subtests was assessed on a Pass or Fail basis and is not therefore analysed in the present study.

\section{Procedure}

The national examination in Swedish was administered first, followed by the mathematics examination. Wren and Benson (2004) consider test anxiety in children to be a situation-specific trait; in a similar vein, Zeidner (1991) investigated the effects of varying the time of administration of the Spielberger et al. (1980) Test Anxiety Inventory (TAI), another selfreport inventory designed to measure test anxiety as a situation-specific personality trait. In light of these reports, temporal considerations were taken into account to improve the accuracy and validity of the assessments of individuals' test anxiety reactions. The timing of the self-anxiety test relative to the academic examination has a moderating effect on the anxietyperformance relationship. It is assumed that the emotional and cognitive feedback experienced by the pupil in the immediate aftermath of the test affects the accuracy and validity of their performance expectancies and sense of competency, prompting them to adjust their test anxiety reactions; this should be reflected in their test anxiety scores. However, it was expected that the correlation between test anxiety and achievement would be low during the lead-up to the examinations (Zeidner, 1991). Interestingly, in a comparative study that used the CTAS to assess test anxiety in Finnish and Swedish pupils, the nations were not found to differ significantly. In Finland there are no national examinations, but pupils are assessed on numerous occasions in most subjects throughout their nine years of compulsory schooling, implying that the timing of the anxiety test relative to the examination has relatively little effect (Nyroos et al., 2011). Consequently, the children were asked to complete the CTAS in the classroom immediately after the last subtest in mathematics; they were given the opportunity to refer to the researcher or their class teacher if they were uncertain about a question. The researcher was present on these occasions and was responsible for scoring both the national examinations and CTAS. 


\section{Data Analysis}

To aid interpretation of the results in an educational context and to identify whether pupils with low test anxiety performed better on the national test than the highly test-anxious, the sample was dichotomised based on gender, and test anxiety level (high or low) in terms of total CTAS score, off-task behaviours, autonomic reactions, and thoughts; in each case, the high-low cut-off was defined as the median score for that element of the test. The link between exam performance and levels of test anxiety in groups exhibiting different average levels of test anxiety has been examined by a number of workers (Chapell et al., 2005; $c f$. McDonald, 2001; Spangler, Pekrun, Kramer \& Hofmann, 2002); the approach was discussed in more detail by. While the conversion of a multi-valued discrete variable (e.g. CTAS score) into a dichotomous variable can be problematic (e.g. MacCallum, Zhang, Preacher \& Rucker, 2002), dichotomisation was performed in this work to simplify the interpretation and conceptualization of the results obtained, and to present differences between the groups in a straightforward and easily-grasped fashion. Summary statistics were calculated and correlations between examination scores and dummy-coded test anxiety measures were analysed using SPSS Version 18.0 (PASW). No data was missing.

\section{Results}

Frequencies and means of the scores were first established, relationships between achievement in the national examinations and the other variables were then explored by pointbiserial correlation analysis, and the significance of detected relationships was assessed by $t$ tests and ANOVA. Finally, the degree to which test anxiety levels explained the results of the mathematical and Swedish ability assessments was evaluated by multiple regression analysis. In Table 1 the CTAS scores obtained for our Swedish sample are compared to those of a reference sample described by Wren \& Benson (2004). Note that pupils in the reference sample began school one year earlier than our sample, therefore sets from both grades 3 and 4 of the reference sample are included. The $t$-tests identified significant differences in all variables between the Swedish and reference sample (grades 3 and 4). To examine whether there were any significant mean differences in experienced test anxiety (total, thoughts, off-task behaviours and autonomic reactions) between the genders in the sample, $t$-tests were conducted. Girls scored higher than boys in the thoughts, autonomic reactions and total, but no significant difference was observed, so no further gender analysis was carried out. 
Table 1. Means, Standard Deviations, and t-scores for CTAS results

\begin{tabular}{|c|c|c|c|c|c|c|c|c|}
\hline \multirow[b]{2}{*}{ CTAS } & \multicolumn{4}{|c|}{ Mean $($ Sd) } & \multicolumn{4}{|c|}{ S wedish sample: Gender } \\
\hline & $\begin{array}{l}\text { Swe grade } 3 \\
(\mathrm{n}=40)\end{array}$ & $\begin{array}{l}\text { Control sample grade } 3 \\
\qquad(\mathrm{n}=46)\end{array}$ & $t$-test & $\begin{array}{c}\text { Control sample grade } 4 \\
\qquad(\mathrm{n}=55)\end{array}$ & $t$-test & $\begin{array}{c}\text { Girls } \\
(\mathrm{n}=20)\end{array}$ & $\begin{array}{l}\text { Boys } \\
(\mathrm{n}=20)\end{array}$ & $t$-test \\
\hline thoughts & $22.25(7.14)$ & $29.54(8.51)$ & $-5.418^{* *}$ & $28.07(8.65)$ & $-4.036 * *$ & $24.65(6.78)$ & $20.65(7.09)$ & $\mathrm{p}=.08$ \\
\hline autonomic reactions & $13.25(4.63)$ & $17.15(4.53)$ & $-5.455^{* *}$ & $16.25(5.25)$ & $-3.614 * *$ & $13.55(5.21)$ & $12.95(4.07)$ & $\mathrm{p}=.69$ \\
\hline off task behaviours & $14.38(3.91)$ & $16.07(4.36)$ & $-2.451^{*}$ & $16.65(5.06)$ & $-2.837 * *$ & $14.10(4.20)$ & $14.65(3.67)$ & $\mathrm{p}=.66$ \\
\hline total & $50.33(12.57)$ & $62,76(14.81)$ & $-5.308^{* *}$ & $60.98(16.61)$ & $-4.055^{* *}$ & $52.40(12.77)$ & $48.25(12.33)$ & $\mathrm{p}=.30$ \\
\hline
\end{tabular}

$t$-test: $\mathrm{df}=39, * \mathrm{p}<.05, * * \mathrm{p}<.01$, two-tailed

Scores obtained in the Swedish and mathematics examinations by the high and low scoring groups for each CTAS measurement are presented in Table 2. To examine whether there were any mean differences in performance in the different subtests and total scores in mathematics and Swedish between pupils who obtained high and low CTAS scores, one-way ANOVA was applied. No significant differences were observed between these groups' performance in Mental arithmetic, Time, Number understanding, Fractions, or Mathematics total. For performance in Written arithmetic there was a significant difference between high- and low-scoring groups in CTAS-thoughts $F(1,38)=6.915, p<0.05$. For performance in Area \& volume there was a significant difference between high- and low scoring groups in CTAStotal and CTAS-autonomic reactions; $F(1,38)=5.558, p<0.05$ and $F(1,38)=4.726, p<0.05$, respectively. For performance in Reading comprehension of fiction, Reading comprehension of facts and Swedish total there were also significant differences between high and low scoring groups in CTAS-autonomic reactions; $F(1,38)=4.548,7.057$ and 6.981, respectively, $p<$ 0.05 in each case. 
Table 2. Means and Standard Deviations (in parentheses) of scores in the various Subtests in Mathematics and Swedish subtests, and the corresponding overall scores, for students with High $(n=20)$ and Low $(n=20)$ CTAS scores

\begin{tabular}{|c|c|c|c|c|c|c|c|c|}
\hline \multirow[b]{2}{*}{ Variables } & \multicolumn{2}{|c|}{ CTAS thoughts } & \multicolumn{2}{|c|}{ CTAS autonomic reactions } & \multicolumn{2}{|c|}{ CTAS off task behaviours } & \multicolumn{2}{|c|}{ CTAS total } \\
\hline & High & Low & High & Low & High & Low & High & Low \\
\hline Written arithmetic & 10.35 & $12.95(2.24)$ & $10.90(3.46)$ & $12.40(3.15)$ & $11.80(2.97)$ & $11.50(3.78)$ & $11.15(3.51)$ & $12.15(3.20)$ \\
\hline Mental arithmetic & $17.95(2.65)$ & $18.20(2.86)$ & $17.70(2.85)$ & $18.45(2.61)$ & $18.45(2.48)$ & $17.70(2.96)$ & $18.10(2.38)$ & 18.05 (3.09) \\
\hline Time & $11.75(2.53)$ & $12.50(1.10)$ & $12.00(1.26)$ & $12.25(2.51)$ & $12.50(0.95)$ & $11.75(2.59)$ & $12.15(1.18)$ & $12.10(2.55)$ \\
\hline Number understanding & $16.95(2.44)$ & $17.15(1.98)$ & $16.70(2.32)$ & $17.40(2.06)$ & $17.40(2.14)$ & $16.70(2.25)$ & $17.00(2.10)$ & $17.10(2.34)$ \\
\hline Fraction & $18.35(4.68)$ & $19.65(1.76)$ & $19.05(3.27)$ & $18.95(3.90)$ & $20.00(1.41)$ & $18.00(4.67)$ & $19.25(3.19)$ & $18.75(3.95)$ \\
\hline Area \& volume & $6.65(2.23)$ & $7.50(1.82)$ & $6.40(2.16)$ & $7.75(1.74)$ & $7.05(1.85)$ & $7.10(0.15)$ & $6.35(2.23)$ & $7.80(1.61)$ \\
\hline Mathematics total & $82.00(13.84)$ & $87.90(7.39)$ & $82.75(9.24)$ & $87.15(13.00)$ & $87.15(7.92)$ & $82.75(13.84)$ & $83.95(9.10)$ & 85.95 (13.39) \\
\hline Reading comprehension fictio & $16.35(1.60)$ & $16.75(1.74)$ & $15.90(1.80)$ & $17.20(1.24)$ & $16.65(1.69)$ & $16.45(1.67)$ & $16.10(1.86)$ & $17.00(1.34)$ \\
\hline Reading comprehension facts & $16.30(2.36)$ & $15.85(2.48)$ & $15.30(2.90)$ & 16.85 & $16.30(2.36)$ & $15.85(2.48)$ & $15.75(2.79)$ & $16.40(1.96)$ \\
\hline Swedish total & $32.65(3.47)$ & $32.60(3.94)$ & $31.20(4.24)$ & $34.05(2.31)$ & $32.95(3.61)$ & $32.30(3.79)$ & $31.85(4.26)$ & $33.40(2.85)$ \\
\hline
\end{tabular}

Note: Significant differences between means are highlighted in bold.

To explore potential effects of test anxiety, associations between each category of CTAS scores and the scores for each of the mathematics and Swedish subtests were examined by two-tailed correlation analyses. The results showed that there were significant negative correlations (see point-biserial coefficients, $r_{p b}$, in bold cells; Table 3) between: CTASthoughts and scores in Written arithmetic $\left(r_{p b}=-0.428, p<.001\right)$; CTAS-autonomic reactions and scores in Area \& volume $\left(r_{p b}=-0.333, p<0.05\right)$; CTAS-arousals and scores in Reading comprehension of fiction $\left(r_{p b}=-0.396, p<0.05\right)$; CTAS-arousals and scores in Reading comprehension of facts $\left(r_{p b}=-0.327, p<0.05\right)$; CTAS-arousals and scores in Swedish total $\left(r_{p b}=\right.$ -0.394, $p<0.05)$; and CTAS-total and scores in Area \& Volume $\left(r_{p b}=-.357, p<0.05\right)$. 
Table 3. Point-biserial coefficients between CTAS Measurements and scores for the indicated Mathematics and Swedish subtest scores and overall scores

\begin{tabular}{|c|c|c|c|c|c|c|c|c|c|c|c|c|c|c|}
\hline Variables & 1 & 2 & 3 & 4 & 5 & 6 & 7 & 8 & 9 & 10 & 11 & 12 & 13 & 14 \\
\hline 1. CT AS-thoughts & & $.451 * *$ & .250 & $.651^{* *}$ & $.428 * *$ & -.045 & -.216 & -.068 & -.214 & -.183 & -.286 & -.105 & .054 & -.012 \\
\hline 2. CT AS-autonomic reactions & & & .200 & $.700 * *$ & -.226 & -.140 & -.064 & -.161 & .014 & $-.333 *$ & $*-.196$ & $-.396 *$ & $*-.327 *$ &.$- .394 *$ \\
\hline 3. CT AS-off task behaviours & & & & $.400 *$ & .045 & .140 & .193 & .161 & .285 & -.012 & .196 & .061 & -.095 & .090 \\
\hline 4. CTAS-total & & & & & -.151 & .009 & .013 & -.023 & .071 & $-.357 *$ & -.089 & -.274 & -.137 & -.214 \\
\hline 5. Written arithmetic & & & & & & $.376^{*}$ & $.575^{* *}$ & $* .375 *$ & $.349 *$ & $.316^{*}$ & $.723 * *$ & $* .302$ & -.044 & .108 \\
\hline 6. Mental arithmetic & & & & & & & $.521 * *$ & $* .553 * *$ & $* .512 * *$ & .283 & $.758 * *$ & $* .551 * *$ & $* .313 *$ & $.456 * *$ \\
\hline 7. Time & & & & & & & & $.522 * *$ & $* .551 * *$ & $* .385 *$ & $.810 * *$ & $* .402 *$ & .270 & $.360 *$ \\
\hline 8. Number understanding & & & & & & & & & $.480 * *$ & * 249 & $.721 * *$ & $* 442 * *$ & $* .286$ & $.388 *$ \\
\hline 9. Fraction & & & & & & & & & & .140 & $.752 * *$ & $* .087$ & .093 & .101 \\
\hline 10. Area \& Volume & & & & & & & & & & & $.502 * *$ & $* .520 * *$ & $* .394 *$ & $.494 * *$ \\
\hline 11. Mathematics total & & & & & & & & & & & & $.496^{* *}$ & $* .263$ & $.397 *$ \\
\hline 12. Reading comprehension fictic & & & & & & & & & & & & & $.612 * *$ & $855^{* *}$ \\
\hline 13. Reading comprehension facts & & & & & & & & & & & & & & $.933 * *$ \\
\hline 14. Swedish total & & & & & & & & & & & & & & \\
\hline
\end{tabular}

$* \mathrm{p}<.05, * * \mathrm{p}<.01$, two-tailed

Note: Significant correlations are highlighted in bold.

Although the relationships in the above correlation analysis may show the strength and direction of correlations between anxiety components and specific subtests, the influence of potentially covariates should also be established. Thus, to examine the amount of variance in performance in the mathematics and Swedish subtests that test anxiety could explain, multiple regression analyses was applied using the enter method (see Table 4). 
Table 4. Results of Regression Analyses between Scores in Mathematics and Swedish Subtests (Dependent Variables) and CTAS Measurements (Independent Variables)

\begin{tabular}{|c|c|c|c|}
\hline Dependent variables & Independent variab] & $\mathbf{R}^{2}$ & B \\
\hline \multirow[t]{4}{*}{ Written arithmetic } & CTAS total & $.21 *$ & \\
\hline & thoughts & & $-.44 *$ \\
\hline & autonomic reactions & & -.06 \\
\hline & off task behaviours & & .17 \\
\hline \multirow[t]{4}{*}{ Mental arithmetic } & CTAS total & .05 & \\
\hline & thoughts & & -.01 \\
\hline & autonomic reactions & & -.17 \\
\hline & off task behaviours & & .18 \\
\hline \multirow[t]{4}{*}{ Time } & CTAS total & .11 & \\
\hline & thoughts & & -.29 \\
\hline & autonomic reactions & & .01 \\
\hline & off task behaviours & & .26 \\
\hline \multirow[t]{4}{*}{ Number understanding } & CTAS total & .07 & \\
\hline & thoughts & & -.04 \\
\hline & autonomic reactions & & -.19 \\
\hline & off task behaviours & & .21 \\
\hline \multirow[t]{4}{*}{ Fraction } & CTAS total & .18 & \\
\hline & thoughts & & -.35 \\
\hline & autonomic reactions & & .10 \\
\hline & off task behaviours & & $.35 *$ \\
\hline \multirow[t]{4}{*}{ Area \& volume } & CTAS total & .12 & \\
\hline & thoughts & & -.06 \\
\hline & autonomic reactions & & -.32 \\
\hline & off task behaviours & & .07 \\
\hline \multirow[t]{4}{*}{ Mathematics total } & CTAS total & .17 & \\
\hline & thoughts & & -.31 \\
\hline & autonomic reactions & & -.12 \\
\hline & off task behaviours & & .30 \\
\hline \multirow[t]{4}{*}{ Swedish reading comprehension ficti } & CTAS total & .18 & \\
\hline & thoughts & & .07 \\
\hline & autonomic reactions & & $-.45^{*}$ \\
\hline & off task behaviours & & .14 \\
\hline \multirow[t]{4}{*}{ Swedish reading comprehension fact: } & CTAS total & .17 & \\
\hline & thoughts & & .23 \\
\hline & autonomic reactions & & $-.46^{*}$ \\
\hline & off task behaviours & & .13 \\
\hline \multirow[t]{4}{*}{ Swedish total } & CTAS total & $.21 *$ & \\
\hline & thoughts & & .18 \\
\hline & autonomic reactions & & $-.50 * *$ \\
\hline & off task behaviours & & .15 \\
\hline
\end{tabular}

$* p<.05, * * p<.01$

As can be seen in Table 4, CTAS scores explained different proportions of the variance for the mathematics and Swedish subtests. For one subtest, Written arithmetic, $21 \%$ of the variance was explained by the CTAS total model, which was significant; $F(3,36)=3.21, p<$ 0.05, with CTAS-thoughts as a significant predictor. For the combined Swedish total score, a significant model was identified that also explained $21 \%$ of the variance; $F(3,36)=3.12$, $p<$ .05 , with CTAS-autonomic reactions contributing significantly to the shared variance. For Fractions, Swedish reading comprehension of fiction and Swedish reading comprehension of 
facts the models were only of marginal significance $(\mathrm{p}=0.070,0.064$ and 0.074 , respectively).

\section{Discussion and Conclusions}

As noted above, the purpose of the present study was to explore and identify the occurrence of test anxiety in a sample of young Swedish pupils and its relation to pupils' performance in different subtopics. To some extent our results corroborated those of other studies (e.g. Miesner \& Maki, 2007), showing that pupils reporting high test anxiety perform less well in national examinations than those reporting lower test anxiety, but only for some test anxiety components and some subtests. The results revealed that test anxiety-autonomic reactions scores were significantly related to Area \& volume, Reading comprehension of facts, Reading comprehension of fiction and Swedish total scores. CTAS-thought scores were significantly related only to scores for Written arithmetic. Overall, total CTAS scores for test anxiety were significantly related to the Area \& volume scores. Notwithstanding, the level of reported test anxiety is low in present sample, which also is in correspondence with theories of the onset and the development of test anxiety (e.g. Pekrun, 2000).

Regression analyses were conducted to examine how test anxiety was related to performance in each of the mathematics and Swedish subtests. Overall, test anxiety explained 21 $\%$ of the variance in Written arithmetic and total Swedish scores, respectively. Analysis of the relationships between subscales of test anxiety and performance in specific subtests showed that anxious thoughts and autonomic reactions were significantly associated with Written arithmetic and Swedish total scores, respectively. While some research (Putwain, 2008) has shown that for older pupils, mathematics is usually mentioned as the subject causing most anxiety; Araki (1992) found that for younger children tests in mathematics produced less stress than language tests. The pupils considered in present study were also given assignments in mathematics more frequently than reading and comprehension tasks in their day-to-day schooling; this may have enabled them to adapt to testing, reducing their levels of test anxiety (Roediger, McDaniel \& McDermott, 2006). In addition, teaching of the sample group regularly included solving mathematical problems and working on the first four rules of arithmetic in assessment-like situations, but the pupils had not yet been taught Area \& volume in any depth. Therefore, the pupils in this study might have found Swedish and Area \& volume tests particularly stressful, as manifested in emotional states, such as autonomic reactions (Meijer, 
2001). In contrast to the findings of Chung et al. (2005), we found that autonomic reactions had the strongest negative influence on test performance. This could have been due to the young age of pupils in the present sample (Wigfield \& Eccles, 1998). Scores for the subtest Written arithmetic (i.e. algorithms) were the only mathematics scores that were significantly related to test anxiety, with the component thoughts as a significant predictor. This may be because children at this age have not yet begun to learn the rules of algorithms or these mathematical procedures (Geary, Hoard \& Hamson, 1999; Lithner, 2008) and therefore might experience more stress in this subtest. However, the pupils in this study had previously worked with algorithms and found them challenging. This might explain why the CTAS subcomponent thoughts correlated with poor performance in Written arithmetic in this study, since worry, the cognitive element of anxiety, is believed to be more permanent than the emotional component (Wigfield \& Eccles, 1989).

Researchers have found a consistent negative relationship between test anxiety and success during testing (Stöber \& Pekrun, 2004). However, this picture does not correspond with younger pupils' experiences of examinations (Zeidner, 2007). The Swedish children in this study reported lower levels of test anxiety compared to the American reference sample, both in age and in grade (Wren \& Benson, 2004). There could be several explanations for this. Firstly, the No Child Left Behind Act of 2001 requires states in the U.S. to develop and implement assessments in basic skills for all pupils in certain grades, in order to receive federal funding for schools (Lowe et al., 2008). Pupils in the reference sample may have been strongly affected by undergoing these high-stakes examinations, explaining their higher reported test anxiety ( $c f$. Osborne, 2006). The National Board of Education in Sweden specifically emphasised that the new national examinations for grade 3 should minimise the test situation and the examinations should be integrated naturally in teaching; avoiding overpreparation with a focus on effort and attainment to help pupils become more confident in their own performance (Connor, 2003). Thus, Swedish pupils might not interpret the examinations as an external pressure. Another factor contributing to the differences between samples could be the young age of the pupils in our sample, since there are indications that test anxiety is a learned condition (development of which varies amongst individuals) that is not prevalent in young children (Lowe \& Lee, 2008). Swedish pupils in general take few examinations (OECD, 2005). Hence, our sample has minor experience of tests and might also have been too young to have been affected by stress in test situations. Test anxiety was however reported by pupils in the sample. The finding that test anxiety was most obvious in the subs- 
cale autonomic reactions corresponds with the hypothesis of Wigfield and Eccles (1989), that children's first experience of anxiety is dominated by emotions. This implies that emotionality, as a state rather than a predisposition, was not yet established in these young pupils as a disposition for stress reactions towards tests (Meijer, 2001).

In summary, this exploratory study has shown that test anxiety seems not to be a general problem but related to different test subject and subtest topics. Scores for the national examination in Swedish seem to be more affected by test anxiety, and specifically by the subcomponent autonomic reactions. As an exploratory study, possibilities for future research have been identified in relation to contextual and content factors in primary education. Girls reported more test anxiety than boys, although this was of only marginal significance in relation to CTAS-thoughts. Written arithmetic (algorithms) appears to produce anxiety even in pupils of the young age in this study. Implications of this study for the mathematics classroom is that the worrisome thoughts connected with Written arithmetic might injure the learning of the, in mathematics education, central algorithms (Ross, 1998). Since test-related anxiety in children can discourage them from learning (Trymms \& Merrell, 2007) this could seriously harm their understanding of algorithms. For the Swedish classroom the pedagogical implications of the the observed relationships between test anxious-autonomic reactions and Reading comprehension (for both factual material and fiction) could mean that it might be helpful to incorporate more tests and test-like scenarios into the day-to-day teaching of Swedish. Increased familiarity with tests on reading and test situations involving reading, understanding, and answering could decrease the stress pupils experience during examinations of this kind (Kalechstein, Hocevar \& Kalechstein, 1988). Standardised assessments are here to stay and pupils are going to be exposed to them in school (Keogh, Bond, French, Richards \& Davis, 2004), they should therefore be given opportunities to get accustomed to sitting examinations. Finally, since the concept of test anxiety will be new to many primary schoolteachers in Sweden, it is not clear how an understanding of test anxiety will be integrated into the Swedish educational context. It is therefore important to investigate school and teacher practices, and to ascertain the mechanism(s) whereby examination anxiety might produce debilitating effects.

This is a small-scale study with some real limitations, but it demonstrates low levels of test anxiety in young pupils and it suggests important implications for Written arithmetic. It could be that the observed significant relationships between test anxiety subcomponents and different topics in Swedish and Mathematics were due to timing; the pupils examined had not 
been taught some of the mathematical and Swedish topics that arose in the examinations, and the CTAS was administrated after the exams had concluded. However, timing does not seem to affect scores for the different subcomponents, since the $t$-values for the pupils examined in this work did not differ from those for the control sample, and there were no differences in model fit when comparing a group of Swedish pupils to another from Finland ( $c f$. Nyroos et al., 2011). The pupils examined in this work had been taught the material on the examinations in an order and style that is representative of common practices used throughout Sweden, and so it is likely that the findings reported herein are also representative. We therefore wish to emphasise the importance of teaching or otherwise imparting adaptive coping behaviour, focus on the task at hand, and emotional regulation during formal education ( $c f$. Onyeizugbo, 2010; Spangler et al., 2002). The benefits of specific relaxation procedures have been shown to be particularly significant for stressful procedures involving reading ( $c f$. Spillios \& Janzen, 1983). 


\section{References}

Araki, N. (1992). Test anxiety in elementary school and junior high school students in Japan, Anxiety, Stress, \& Coping, 5(3), 205-215.

Beidel, D. C., \& Turner, S. M. (1988). Comorbidity of test anxiety and other anxiety disorders in children. Journal of Abnormal Child Psychology, 16(3), 275-287.

Birenbaum, M., \& Gutvirtz, Y., (1993). The relationship between test anxiety and seriousness of errors in algebra, Journal of Psychoeducational Assessment, 11(1), 12-19.

Bodas, J., Ollendick, T. H., \& Sovani, A. V. (2008). Test anxiety in Indian children: a crosscultural perspective. Anxiety, Stress, \& Coping, 21(4), 387-404.

Boekaerts, M., Otten, R., \& Voeten, R. (2003). Examination performance: Are student's causal attributions school-subject specific? Anxiety, Stress, \& Coping, 16(3), 331-342.

Chapell, M. S., Blanding, B., Silverstein, M. E., Takahahi, M., Newman, B., Gubi, A., \& McCann, N. (2005). Test anxiety and academic performance in undergraduate and graduate students. Journal of Educational Psychology, 97(2), 268-274.

Chung, G. K. W. K., O’Neil, H. F., Delacruz, G. C., \& Bewley, W. L. (2005). The role of anxiety on novices' rifle marksmanship performance. Educational Assessment, 10(3), 257-275.

Connor, M. J. (2003). Pupil stress and standard assessment tasks (SATs) An update. Emotional and Behavioural Difficulties, 8(2), 101-107.

Connors, L., Putwain, D., Woods, K., \& Nicholson, L. (2009, September). Causes and consequences of test anxiety in Key Stage 2 pupils: the mediational role of emotional resilience. Symposium presented at the British Educational Association Conference, Manchester, UK.

Doig, B. (2006). Large-scale mathematics assessment: looking globally to act locally. Assessment in Education, 13(3), 265-288.

Eurydice. (2009). National Testing of Pupils in Europe: Objectives, Organisation and Use of Results, Retrieved March 16, 2010, from: http://www.eurydice.org

Finch. J. A. J., \& McIntosch, J. A. (1990). Assessment of anxieties and fears in children. In A. M. La Greca (Ed.), Through the eyes of the child: Obtaining self-reports from children and adolescents (234-258). Boston: Allyn and Bacon. 
Geary, D. C., Howard, M. K., \& Hamson, C. O. (1999). Numerical and arithmetical cognition: patterns of function and deficits in children at risk for a mathematical disability. Journal of Experimental Child Psychology, 74(3), 213-239.

Gibbs, C. (1995). What do we mean by equity in relation to assessment? Assessment in Education: Principles, Policy \& Practice, 2(3), 271-282.

Harlen, W. (2007). The Quality of Learning: assessment alternatives for primary education (Primary Review Research Survey 3/4), Cambridge: University of Cambridge Faculty of Education.

Hopko, D. R., McNeil, D. W., Zvolensky, M. J., \& Eifert, G. H. (2001). The relation between anxiety and skill in performance-based anxiety disorders: a behavioural formulation of social phobia. Behaviour Therapy, 32, 185-207.

Hugo, M. (2007). Liv och lärande $i$ gymnasieskolan: en studie om elevers och lärares erfarenheter $i$ en liten grupp på gymnasieskolans individuella program [Life and learning in upper-secondary school: a study in students' and teachers' experiences in a small group in the individual programme at upper-secondary school; in Swedish] (Dissertation No 2). Jönköping University: School of Education and Communication.

Ialongo, N, Edelsohn, G., Werthamer-Larsson, L., Crockett, L., \& Kellam, S. (1994). The significance of self-reported anxious symptoms in first grade children. Journal of $A b$ normal Child Psychology, 22(4), 441-456.

Kalechstein, P. B. W., Hocevar, D. \& Kalechstein, M. (1988). Effects of test-wiseness training on test anxiety, locus of control and reading achievement in elementary school children. Anxiety, Stress, \& Coping, 1(3), 247-261.

Keogh, E., Bond, F. W., French, C. C., Richards, A. \& Davis, R. E. (2004). Test anxiety, susceptibility to distraction and examination performance. Anxiety, Stress, \& Coping, $17(3), 241-252$.

King M. I., Ollendick, T. H., Gullone, E. (1991). Test anxiety in children and adolescents. Australian Psychologist, 26(1), 25-32.

Korp, H. (2003). Kunskapsbedömning - hur, vad och varför [Assessing knowledge-how, what and why?; in Swedish] (Forskning i fokus No 13. Myndigheten för skolutveckling. Stockholm: Fritzes förlag. 
Krantz, J. (2010). Styrning och mening: anspråk på professionellt handlande i lärarutbildning och skola [Governance and meaning: claiming professional dealing in teacher education and school; in Swedish] (Dissertation No 181). Växjö: Växjö University.

Legrand, L. N., McGue, M., \& Iacono, W. G. (1999). A twin study of state and trait anxiety in childhood and adolescence. Journal of Child Psychology and Psychiatry, 40(6), 953958.

Lindberg, V. (2005). Svensk forskning om bedömning och betyg 1990-2005 [Swedish research in assessment and grades; in Swedish]. Studies in Educational Policy and Educational Philosophy, 2005:1. Retrieved May, 5, 2009, from: www.upi.artisan.se

Lithner, J. (2008). A research framework for creativity and imitative reasoning. Educational Studies for Mathematics, 67(3), 255-276.

Logie, R. H. (1999). Working memory. The Psychologist, 12(4), 174-178.

Lowe, P. A., \& Lee, S. W. (2008). Factor structure of the Test Anxiety Inventory for Children and Adolescents (TAICA) scores across gender among students in elementary and secondary school settings. Journal of Psychoeducational Assessment, 26(3), 231-246.

Lowe, P. A., Lee, S. W., Witterborg, K. M., Prichard, K. W., Luhr, M. E., Cullinan, C. M., Mildren, B. A., Raad, J. M., Cornelius, R. A., \& Janik, M. (2008). The Test Anxiety Inventory for Children and Adolescents (TAICA). Journal of Psychoeducational Assessment, 26(3), 215-230.

macCallum, R. C., Zhang, S., Preacher, K. J., \& Rucker, D. D. (2002). On the practice of dichotomization of quantitative variables. Psychological Methods, 7(1), 19-40.

Martino, W. (1997). A bunch of arseholes: Exploring the politics of masculinity for adolescent boys in schools. Social Alternatives. 16(3), 39-43.

McDonald, A. S. (2001). The prevalence and effects of test anxiety in school children. Educational Psychology, 21(1), 89-101.

McLean, J. F., \& Hitch, G. J. (1999). Working memory impairments in children with specific arithmetic learning difficulties. Journal of Experimental Child Psychology, 74(3), 240260.

Meijer, J. (2001). Learning potential and anxious tendency: test anxiety as a bias factor in educational testing. Anxiety, Stress, \& Coping, 14(3), 337-362. 
Miesner, M., T., \& Maki, R. H. (2007). The role of test anxiety in absolute and relative metacomprehension accuracy. European Journal of Cognitive Psychology, 19(4), 650-670.

Mons, N. (2009). Theoretical and Real Effects of Standardised Assessment. Retrieved March, 16, 2010, from http://www.eurydice.org

Nasser, F., Takahashi, T., \& Benson, J. (1997). The structure of test anxiety in Israeli-Arab high school students: an application of confirmatory factor analysis with miniscales. Anxiety, Stress, \& Coping, 10(2), 129-151.

Natriello, G. (1987). The impact of evaluation processes on students Educational Psychologist. 22(2), 155-175.

Newstead, K. (1998). Aspects of children's mathematics anxiety. Educational Studies in Mathematics, 36(1), 53-71.

Nicholls, J. G., \& Miller, A .T. (1986). Conceptions of ability in children and adults. In R. Schwarzer (Ed.), Self-related Cognitions in Anxiety and Motivation (265-284). Hillsdale, N.J.: Erlbaum.

Nyroos, M., Korhonen, J., Linnanmäki, K, \& Svens-Liavåg, C. (submitted). A cross-national comparison of test anxiety in Swedish and Finnish grade 3 pupils: measured by the CTAS. Education Inquiry.

O’Donnell, S., Sargent, C., Byrne, C., White, E., \& Gray, J. (2009). INCA Comparative Tables, International Review of Curriculum and Assessment Frameworks Internet Archive (England: Qualifications and Curriculum Development Agency (QCDA) and National Foundation for Educational Research (nfer). Retrieved March, 3, 2010 from http://www.inca.org.uk

OECD. (2005). Education at a glance: OECD indicators. Centre for Educational Research and Innovation, Paris: Organisation for Economic Co-operation and Development.

Onyeizugbo, E. U. (2010). Self-efficacy, gender and trait anxiety as moderators of test anxiety. Electronic Journal of Reserach in Educational Psychology, 8(1), 299-312.

Osborne, J. W. (2006). Gender, stereotype threat, and anxiety: psychological and cognitive evidence. Electronic Journal of Reserch in Educational Psychology, 4(1), 109-138. 
Owens, M., Stevenson, J., Norgate, R., \& Hadwin, J. (2008). Processing efficiency theory in children: Working memory as a mediator between trait anxiety and academic performance. Anxiety, Stress, \& Coping, 21(4), 417-430.

Paris, S. G., Lawton, T. A., Turner, J. C., \& Roth, J. L. (1991). A developmental perspective on standardized achievement testing. Educational Researcher, June-July, 20(5), 12-20.

Pekrun, R. (2000). A social-cognitive, control-value theory of achievement emotions. In J. Heckhausen (Ed.) Motivational Psychology of Human Development: developing motivation and motivational development, Advances in psychology 131(143-163). Amsterdam: Elsevier.

Pekrun, R., Goetz, T., Perry, R. P., Kramer, K., Hochstadt, M, \& Molfenter, S. (2004). Beyond test anxiety: Development and validation of the test emotions questionnaire (TEQ). Anxiety, Stress, \& Coping 17(3), 287-316.

Pekrun, R., Goetz, T., Titz, W., \& Perry, R. P. (2002). Academic emotions in students' selfregulated learning and achievement: a program of quality and quantitative and research. Educational Psychologist, 37(2), 91-105.

Pellegrino, J. W., \& Goldman, S. R. (2008). Beyond rhetoric: realities and complexities of integrating assessment into classroom teaching and learning. In C. A. Dwyer (Ed.) (2008), The Future of Assessment: Shaping teaching and learning (7-52). New York: Lawrence Erlbaum Associates.

Putwain, D. W. (2008). Test anxiety and GCSE performance: the effect of gender and socioeconomic background. Educational Psychology in Practice, 24(4), 319-334.

Rand, P., Lens, W., \& Decock, B. (1991). Negative motivation is half the story: achievements motivation combines positive and negative motivation. Scandinavian Journal of Educational Research, 35(1), 13-30.

Reay, D., \& William, D. (1999). 'I'll be a nothing': structure, agency and the construction of identity through assessment. British Educational Research Journal, 25(3), 343-354.

Richmond, B. O., Rodrigo, G. \& de Rodrigo, M. (1988). Factor structure of Spanish version of the revised children's manifest anxiety scale in Uruguay. Journal of Personality Assessment, 52(1), 165-170. 
Robertson, I. (2005). Issues relating to curriculum, policy and gender raised by national and international surveys of achievement in mathematics. Assessment in Education, 12(3), 217-236.

Roediger, H. L. III, McDaniel, M., \& McDermott, K. (2006). Test enhanced learning. APS Observer, 19(3).

Ross, K. A. (1998). Doing and proving: The place of algorithms and proofs in school mathematics. The American Mathematical Monthly, 105(3), 252-255.

Sarason, S. B., Davidson, K. S., Lighthall, F. F., Waite, R. R., \& Ruebush, B. K. (1969). Anxiety in elementary school children. New York: John Wiley \& Sons, Inc.

Seipp., B., \& Schwarzer, C. (1996). Cross-cultural anxiety research: A review. In C. Schwarzer, \& M. Zeidner (Eds.), Stress, anxiety and coping in academic settings. Tubingen, Germany: Francke-Verlag.

Shepard, L .A. (2000). The role of assessment in a learning culture. Educational Researcher, October, 29(7), 4-14.

Skelton, C. (2001). Schooling the boys: Masculinity and primary education. Buckingham: Open University Press.

Skolverket [National Agency of Education]. (2007). PIRLS 2006 Läsförmåga hos elever i årskurs 4: i Sverige och i världen [PIRLS 2006 Reading comprehension in pupils in grade 4: in Sweden and in the world; in Swedish] (Rapport 305). Stockholm: Fritzes Kundservice.

Skolverket [National Agency of Education]. (2010). Ämnesproven i grundskolans årskurs 3: en redovisning av utprövningsomgången 2009 [National examinations in compulsory school grade 3: a report from the pilot phase 2009; in Swedish]. Retrieved March, 8, 2010, from http://www.skolverket.se/sb/d/2854

Spangler, G., Pekrun, R., Kramer, K. \& Hofmann, H. (2002). Students' emotions, physiological reactions, and coping in academic exams. Anxiety, Stress, \& Coping, 15(4), 413432.

Spielberger, C. D., Gonzales, H. P., Taylor, C. J., Anton, W. D., Algaze, B., Ross G. K., Westberry, L. G. (1980). Test Anxiety Inventory. Palo Alto, California: Consulting Psychologist Press. 
Spillios, J. C. \& Janzen, H. L. (1983). Anxiety and learning disabilites. School Psychology International, 4(3), 141-152.

Stöber, J., \& Pekrun, R. (2004). Advances in test anxiety research. Anxiety, Stress, \& Coping, $17(3), 205-211$.

Stone, W.L., \& Lemanek, K.L. (1990). Developmental issues in children's self-reports. In La Greca, A.M. (Ed.), Through the eyes of a child: Obtaining self-reports from children and adolescents (3-17). Allyn \& Bacon, Boston.

Swedish Research Council. (2006). Good Research Practise - What is it? Views, guidelines and examples. B Gustafsson, Hermerén G and Petersson B (Eds.). Stockholm: The Swedish Research Council.

Trymms, P. \& Merrell, C. (2007). Standards and quality in English primary schools over time: the national evidence (primary review research in English survey 4/1). Cambridge, UK: The University of Cambridge Faculty of Education.

Wigfield, A., \& Eccles, J. S. (1989). Test anxiety in elementary and secondary school students. Educational Psychologist, 24(2), 159-183.

Wolf, L. F. \& Smith, J. K. (1995). The consequence of consequence: motivation, anxiety, and test performance. Applied Measurement in Education, 8(3), 227-242.

Wren, D. G., \& Benson, J. (2004). Measuring test anxiety in children: scale development and internal construct validation. Anxiety, Stress, \& Coping, 17(3), September, 227-240.

Yousefi, F., Bte Mansor, M., Bte Juhari, R., Redzuan, M., Abu Talib, M., Kumar, V., \& Naderi, H. (2009). Memory as mediator between test-anxiety and academic achievement in high school students. European Journal of Scientific Research, 35(2), 274280.

Zeidner, M. (1990). Does test anxiety bias scholastic aptitude test performance by gender and social group? Journal of Personality Assessment, 55(1\&2), 145-160.

Zeidner, M. (1991). Test anxiety and aptitude test performance in an actual college admissions testing situation: temporal considerations, Personality and Individual Differences, 12(2), 101-109.

Zeidner, M. (1998). Test Anxiety: The State of the Art. New York: Kluwer Academic Publishers. 
Zeidner, M. (2007). Test anxiety in educational contexts: Concepts, findings, and future directions. In P. A. Schutz, \& R. Pekrun (Eds.), Emotion and education (165-184). San Diego, CA: Elsevier INC.

Zeidner, M., \& Matthews, G. (2003). Test anxiety. In R. Fernández-Ballesteros (Ed.), Encyclopedia of Psychological Assessment, Vol 2 M-Z (964-969). London: SAGE Publications.

Zeidner, M., \& Matthews, G. (2005). Evaluation anxiety: current theory and research. In A. J. Elliot, \& C. S. Dewck (Eds.), Handbook of Competence and Motivation (141-162). New York: The Guilford Press. 